\title{
PROMIENIOTWÓRCZOŚĆ NATURALNA BETONU ZE ZMIENNYM DODATKIEM MIKROKRZEMIONKI ZAGĘSZCZONEJ (SF) I KRZEMIONKOWYCH POPIOŁÓW LOTNYCH (FA)
}

\author{
Damian Marek Gil ${ }^{\varpi}$, Grzegorz Ludwik Golewski \\ Wydział Budownictwa i Architektury, Politechnika Lubelska, Lublin
}

\begin{abstract}
STRESZCZENIE
Promieniowanie naturalne towarzyszy ludzkości od początku jej istnienia. Jest ono obecne w powietrzu, wodzie, glebie czy skałach, a także w materiałach budowlanych. Człowiek może być narażony w mniejszym bądź większym stopniu na otaczającą go promieniotwórczość. W pracy przedstawiono wyniki badań promieniotwórczości betonu z różną kompozycją dodatku przykładowego krzemionkowego popiołu lotnego oraz mikrokrzemionki zagęszczonej. Udowodniono, że materiał o podwyższonej aktywności radioaktywnej może być w bezpieczny sposób wykorzystywany do produkcji betonu i dodatkowo spełnia restrykcyjne wymagania polskiego rozporządzenia Rady Ministrów czy dyrektywy 2013/59/Euratom w zakresie ochrony przed promieniowaniem aktywnym.
\end{abstract}

Słowa kluczowe: promieniotwórczość naturalna, radionuklidy, beton, popiół lotny, zagęszczony pył krzemionkowy, bezpieczeństwo radioaktywne

\section{WSTĘP}

Promieniowanie jest nieodłącznym elementem życia na Ziemi, a jego źródłem jest promieniowanie kosmiczne oraz część pierwiastków występujących w: skorupie ziemskiej, skałach, glebie, wodzie, powietrzu, organizmach żywych i pożywieniu. Materiały budowlane pochodzenia mineralnego zawierają w swoim składzie naturalne pierwiastki promieniotwórcze. Promieniotwórczości naturalnej nie da się uniknąć i uznaje się, że promieniowanie to jeden ze sposobów wysyłania, przenoszenia energii w postaci np. światła, ciepła, cząstek materii czy fal elektromagnetycznych. Jednym $z$ rodzajów promieniowania jest promieniowanie jonizujące, które przechodząc przez materię, ulega pochłanianiu lub zostaje rozproszone. Źródłem takiego promieniowania są np. substancje, które generują promieniowanie alfa, beta, gamma (Kuliczkowski, Pluta i Zwierzchowski, 1993).

Ze względu na to, że materiały budowlane, odpady czy surowce stosowane do produkcji materiałów budowlanych również generują promieniowanie, każda osoba przebywająca w przegrodach budowlanych jest narażona na dawkę skuteczną (efektywną) promieniowania jonizującego w ciągu roku 3,55 mSv (GUS, 2017). W tabeli 1 przedstawiono źródła promieniowania $\mathrm{w}$ środowisku pochodzenia naturalnego. Wielkości dawek granicznych obowiązujących w Polsce zgodnie z rozporządzeniem Rady Ministrów z 2005 roku w sprawie dawek granicznych promieniowania jonizującego (Dz.U. 2005 nr 20, poz. 168) wynoszą odpowiednio:

- $20 \mathrm{mSv} \cdot \mathrm{rok}^{-1}$ dla osób narażonych zawodowo oraz praktykantów i studentów (uczniów) w wieku

\footnotetext{
${ }^{凶}$ d.gil@pollub.pl
} 
18 lat i powyżej (dawka może być w danym roku kalendarzowym przekroczona do wartości $50 \mathrm{mSv}$ pod warunkiem, że w ciągu kolejnych 5 lat kalendarzowych nie przekroczy $100 \mathrm{mSv}$ );

- $6 \mathrm{mSv} \cdot \mathrm{rok}^{-1}$ dla praktykantów i studentów (uczniów) w wieku 16-18 lat;

- $1 \mathrm{mSv} \cdot$ rok $^{-1}$ dla osób z ogółu ludności oraz praktykantów i studentów (uczniów) w wieku poniżej 16 lat (dawka może być w danym roku kalendarzowym przekroczona pod warunkiem, że w ciągu kolejnych 5 lat kalendarzowych nie przekroczy $5 \mathrm{mSv}$ ).

Materiały budowlane generują promieniowanie, ponieważ są wytwarzane z surowców takich jak: piasek, glina, gips, wapno, które ponadto mogą zawierać dodatki w postaci popiołów lotnych czy żużli wielkopiecowych.

Na podstawie analizy danych z tabeli 1 widać wyraźnie, że człowiek najbardziej narażony jest na promieniowanie występujące wewnątrz budynków. Promieniowanie to wynika przede wszystkim z obecności w konstrukcji budynków materiałów budowlanych za- stosowanych do jego wykonania. Materiały budowlane generują głównie promieniowanie gamma oraz alfa $\left({ }^{40} \mathrm{~K}\right.$ - potas, ${ }^{238} \mathrm{Ur}$ - uran, izotopy szeregu uranoworadowego: ${ }^{226} \mathrm{Ra}$ - rad i ${ }^{222} \mathrm{Rn}$ - radon oraz ${ }^{232} \mathrm{Tr}$ - tor wraz z izotopami, tj. ${ }^{228} \mathrm{Th}$ ), które jest niekorzystne dla człowieka po przekroczeniu określonych granic (Kovler, 2011; Zakrzewski, 2015).

W tabeli 2 przedstawiono wyniki pomiarów stężeń radionuklidów oraz wartości wskaźnika aktywności wybranych materiałów budowlanych, surowców i odpadów przemysłowych (GUS, 2017).

Zgodnie z rozporządzeniem Rady Ministrów z 2007 roku w sprawie zawartości promieniotwórczych izotopów w surowcach i materiałach budowlanych (Dz.U. $2007 \mathrm{nr} 4$, poz. 29) dopuszczalne dawki promieniowania wynosza: $f_{1} \leq 1,2 ; f_{2} \leq 240 \mathrm{~Bq} \cdot \mathrm{kg}^{-1}$. Istotne jest więc, aby generować jak najmniej materiałów promieniotwórczych takich jak popioły lotne. Stwierdzono bowiem, że często odpady tego typu emitują dość wysokie stężenie radionuklidów, tym samym mogą przekraczać dopuszczalny wskaźnik $f_{1}$ bądź $f_{2}$. W takiej sytuacji najlepszym

Tabela 1. Wartość średnich rocznych dawek skutecznych otrzymywanych przez jednego mieszkańca Polski z naturalnych i ze sztucznych źródeł promieniowania w 2016 roku (GUS, 2017)

Table 1. Values of average annual values of average annual individual effective doses received by inhabitants of Poland from natural and artificial sources of radiation in 2016 (GUS, 2017)

\begin{tabular}{|c|c|}
\hline Źródło radioaktywności - Source of radioactivity & $\begin{array}{l}\text { Dawka }\left[\mathrm{mSv} \cdot \text { rok }^{-1}\right] \\
\text { Dose }\left[\mathrm{mS} \cdot \text { year }^{-1}\right]\end{array}$ \\
\hline $\begin{array}{l}\text { Promieniowanie na zewnątrz budynków } \\
\text { Radiation outside of buildings }\end{array}$ & 0,126 \\
\hline $\begin{array}{l}\text { Promieniowanie wewnątrz budynków } \\
\text { Radiation inside buildings }\end{array}$ & 1,639 \\
\hline $\begin{array}{l}\text { Promieniowanie kosmiczne } \\
\text { Cosmic radiation }\end{array}$ & 0,390 \\
\hline $\begin{array}{l}\text { Radionuklidy inkorporowane (naturalne: radon, toron) } \\
\text { Radionuclides incorporated (natural: radon, toron) }\end{array}$ & 0,277 \\
\hline $\begin{array}{l}\text { Pochodzenia sztucznego (związane z elektrowniami jądrowymi i opadami promieniotwórczymi) } \\
\text { Artificial origin (associated with nuclear power plants and radioactive fallout) }\end{array}$ & 0,008 \\
\hline $\begin{array}{l}\text { Źródło promieniowania stosowane w diagnostyce medycznej } \\
\text { The radiation source used in medical diagnosis }\end{array}$ & 1,102 \\
\hline $\begin{array}{l}\text { Narażenie zawodowe (np. kopalnie węgla kamiennego) } \\
\text { Occupational exposure (e.g. coal mines) }\end{array}$ & 0,002 \\
\hline $\begin{array}{l}\text { Przedmioty powszechnego użytku } \\
\text { Consumer items }\end{array}$ & 0,001 \\
\hline Razem - In total & 3,550 \\
\hline
\end{tabular}


Gil, D.M., Golewski, G.L. (2019). Promieniotwórczość naturalna betonu ze zmiennym dodatkiem mikrokrzemionki zagęszczonej (SF) i krzemionkowych popiołów lotnych (FA). Acta Sci. Pol. Architectura 18 (1), 59-67, DOI: 10.22630/ASPA.2019.18.1.7

Tabela 2. Stężenia radionuklidów naturalnych i wartości wskaźników aktywności $f_{1}$ i $f_{2}$ w wybranych surowcach oraz materiałach budowlanych pomierzone w latach 2003-2016 (GUS, 2017)

Table 2. Natural radionuclides concentrations and values of $f_{1}$ and $f_{2}$ activity indices in selected raw materials and construction products in 2003-2016 (GUS, 2017)

\begin{tabular}{|c|c|c|c|c|c|}
\hline \multirow{2}{*}{$\begin{array}{l}\text { Rodzaj surowca lub materiału } \\
\text { budowlanego } \\
\text { Raw material or construction } \\
\text { product }\end{array}$} & \multicolumn{3}{|c|}{$\begin{array}{c}\text { Stężenie radionuklidów } \\
\text { Radionuclides concentration } \\
{\left[\mathrm{Bq} \cdot \mathrm{kg}^{-1}\right]}\end{array}$} & \multicolumn{2}{|c|}{$\begin{array}{c}\text { Wartość wskaźnika aktywności } \\
\text { Values of activity indices } \\
{\left[\mathrm{Bq} \cdot \mathrm{kg}^{-1}\right]}\end{array}$} \\
\hline & ${ }^{40} \mathrm{~K}$ & ${ }^{226} \mathrm{Ra}$ & ${ }^{232} \mathrm{Tr}$ & $f_{1}$ & $f_{2}$ \\
\hline $\begin{array}{l}\text { Piasek } \\
\text { Sand }\end{array}$ & $0-1230(355)$ & $0-116(30)$ & $0-88(26)$ & $0,00-1,09(0,20)$ & $0-116(30)$ \\
\hline $\begin{array}{l}\text { Glina } \\
\text { Clay }\end{array}$ & $198-1245$ (588) & $26-82(52)$ & $30-64(48)$ & $0,35-0,85(0,61)$ & $26-82(52)$ \\
\hline $\begin{array}{l}\text { Wapno } \\
\text { Lime }\end{array}$ & 10-118 (37) & 10-204 (30) & $1-85(10)$ & $0,00-1,09(0,20)$ & $0-116(30)$ \\
\hline $\begin{array}{l}\text { Popioły lotne } \\
\text { Fly ash }\end{array}$ & $0-8775(813)$ & $0-257(122)$ & $0-148(113)$ & $0,00-0,190(1,26)$ & $0-257(122)$ \\
\hline $\begin{array}{l}\text { Żużel wielkopiecowy } \\
\text { Boiler slag }\end{array}$ & $102-426(217)$ & $42-138(81)$ & $30-52(36)$ & $0,00-0,68(0,43)$ & $42-138(81)$ \\
\hline $\begin{array}{l}\text { Cement } \\
\text { Cement }\end{array}$ & 19-7149 (291) & $0-111(40)$ & $6-72(26)$ & $0,00-2,00(0,10)$ & $0-111(40)$ \\
\hline $\begin{array}{l}\text { Beton komórkowy i lekki } \\
\text { Cellular concrete }\end{array}$ & $105-1015$ (491) & $5-149(68)$ & $3-106(55)$ & $0,00-1,00(0,09)$ & $5-149(69)$ \\
\hline $\begin{array}{l}\text { Betony inne } \\
\text { Other concrete }\end{array}$ & $48-805(434)$ & $5-656(66)$ & 4-383 (47) & $0-3(0,10)$ & $5-656(65)$ \\
\hline $\begin{array}{l}\text { Ceramika } \\
\text { Construction ceramics }\end{array}$ & 0-1368 (669) & $0-214(52)$ & 0-171 (48) & $0-7(0,04)$ & $0-214(52)$ \\
\hline
\end{tabular}

rozwiązaniem jest utylizacja materiałów takich jak FA, które zawierają naturalne pierwiastki promieniotwórcze (Bem, Wieczorkowski i Budzanowski, 2002; Xinwei, Caifeng, Cancan i Wen, 2012; Mamta i in., 2013). Należy mieć na uwadze, że przebywając w pobliżu składowisk FA, człowiek jest narażony na podwyższoną dawkę skuteczną promieniowania generowanego przez pozostałości po spalonym węglu kamiennym (Lubin i in., 1995; Michalik, 2006; Bojakowska, Lech i Wołkowicz, 2008; Olkuski, 2008; Olkuski i Stala-Szlugaj, 2009; Pandit, Sahu i Puranik, 2011). Przy stosowaniu FA do betonów wskaźnik radioaktywności tego materiału jest wyższy w porównaniu do wskaźnika betonu bez dodatków, ale nadal znajduje się w granicach bezpiecznych dla człowieka (Golewski, 2015).

Z uwagi na to, że problem promieniotwórczości naturalnej betonów $\mathrm{z}$ dodatkiem FA został już rozpoznany (Turhan, Arıkan, Yücel, Varinlioğlu i Köse,
2010; Kovler, 2012; Golewski, 2015), w poniższej pracy przedstawiono wyniki badań radioaktywności betonów wykonanych na spoiwach trójskładnikowych, tzn. z łącznym dodatkiem FA i SF.

\section{MATERIA I METODY}

\section{Materiały wykorzystane do badań}

Badania zostały przeprowadzone na krzemionkowych popiołach lotnych - FA, mikrokrzemionce zagęszczonej - SF (rys. 1) oraz betonie o zmiennej zawartości dodatku FA i 10\% substytucie cementu w postaci SF (Gil i Golewski, 2016; 2017a; 2017b).

Oznaczenia poszczególnych kompozycji mieszanek betonowych były następujące:

- $0 \% \mathrm{FA}+10 \% \mathrm{SF}(\mathrm{FA}-00+\mathrm{SF}-10)$,

$-10 \% \mathrm{FA}+10 \% \mathrm{SF}(\mathrm{FA}-10+\mathrm{SF}-10)$,

- $20 \% \mathrm{FA}+10 \% \mathrm{SF}$ (FA-20+SF-10). 


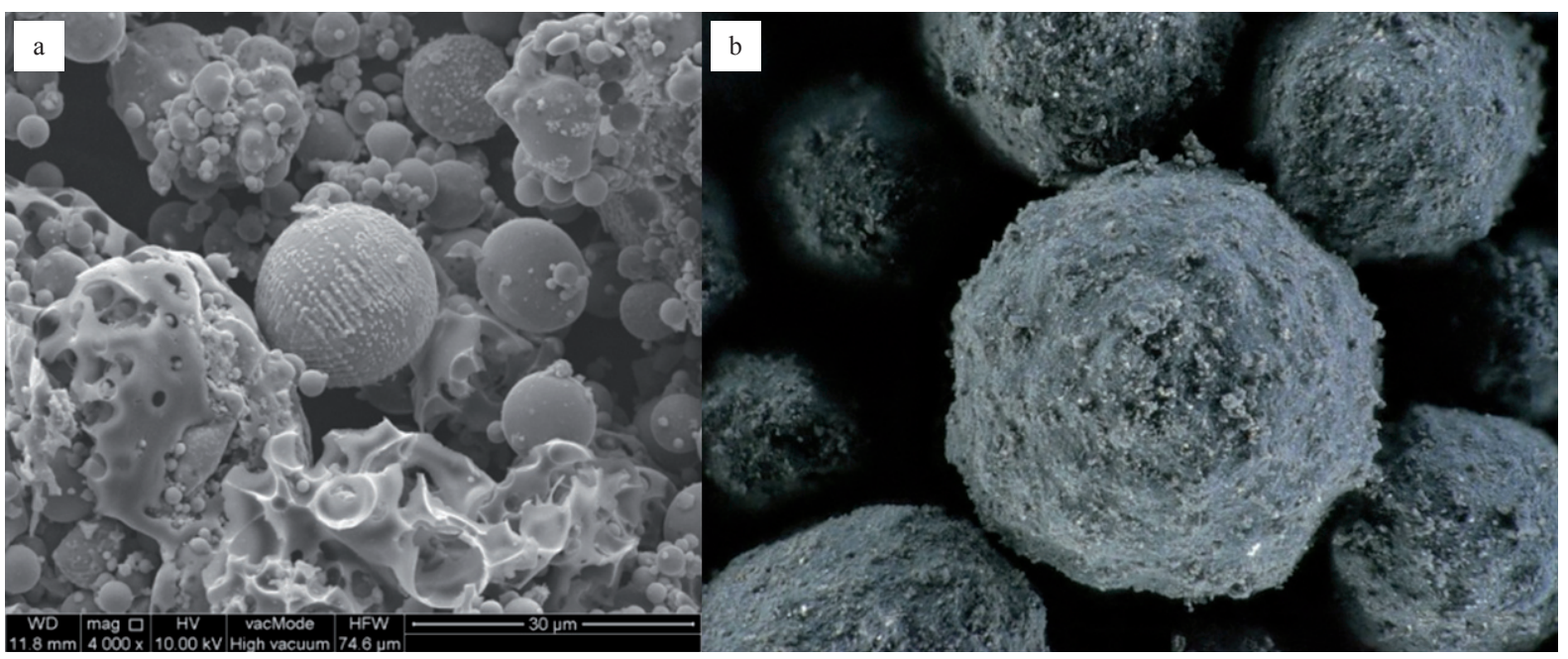

Rys. 1. Obraz mikroskopowy krzemionkowego popiołu lotnego (a) oraz mikrokrzemionki zagęszczonej (b)

Fig. 1. Microscope images of siliceous fly ash (a) and compacted microsilica fume (b)

Mieszanki betonowe wykonano w mieszarce przeciwbieżnej w laboratorium przy wykorzystaniu następujących materiałów: cementu portlandzkiego CEM I 32,5R z cementowni w Ożarowie, kruszywa naturalnego żwirowego 2-8 mm ze złóż w Rokitnie, piasku kopalnego 0-2 mm ze złóż w Niemcach, mikrokrzemionki zagęszczonej z Huty Łaziska SA, krzemionkowych popiołów lotnych z elektrociepłowni w Puławach i plasty- fikatora Stacheplast 125. Skład szczegółowy mieszanek betonowych przedstawiono w tabeli 3 .

Popioły lotne wykorzystane do badań pochodziły z Zakładów Azotowych „Puławy”. Powstały one na skutek spalania pyłu węglowego z węgla kamiennego. W tabeli 4 zestawiano skład chemiczny FA, w których najwięcej jest krzemionki $\left(\mathrm{SiO}_{2}\right)$ oraz tlenku glinu $\left(\mathrm{Al}_{2} \mathrm{O}_{3}\right)$.

Tabela 3. Receptura mieszanek betonowych

Table 3. Recipe of concrete mixtures

\begin{tabular}{|c|c|c|c|c|}
\hline \multirow{2}{*}{$\begin{array}{l}\text { Składnik mieszanki } \\
\text { Component of concrete }\end{array}$} & \multicolumn{4}{|c|}{ Zawartość - Contents $\left[\mathrm{kg} \cdot \mathrm{m}^{-3}\right]$} \\
\hline & FA- $00+$ SF-00 & FA-00+SF-10 & FA-10+SF-10 & FA-20+SF-10 \\
\hline $\begin{array}{l}\text { Cement portlandzki CEM I 32,5R } \\
\text { (cementownia w Ożarowie) } \\
\text { Portland cement CEM I 32.5R } \\
\text { (Ożarów cement factory) }\end{array}$ & 352 & 317 & 282 & 246 \\
\hline $\begin{array}{l}\text { Krzemionkowy popiół lotny } \\
\text { (elektrociepłownia w Puławach) } \\
\text { Siliceous fly ash (Puławy power plant) }\end{array}$ & 0 & 0 & 35 & 70 \\
\hline $\begin{array}{l}\text { Pył krzemionkowy - zagęszczony (Huta Łaziska SA) } \\
\text { Concentrated silica fume (Łaziska Ironworks SA) }\end{array}$ & 0 & 35 & 35 & 35 \\
\hline $\begin{array}{l}\text { Woda (z wodociągu miejskiego) } \\
\text { Water (from urban water supply) }\end{array}$ & 141 & 141 & 141 & 141 \\
\hline $\begin{array}{l}\text { Piasek 0-2 mm (Niemce) } \\
\text { Sand 0-2 mm (Niemce) }\end{array}$ & 646 & 676 & 676 & 676 \\
\hline $\begin{array}{l}\text { Żwir 2-8 mm (żwirownia w Rokitnie) } \\
\text { Gravel 2-8 mm (Rokitno gravel pit) }\end{array}$ & 1205 & 1205 & 1205 & 1205 \\
\hline
\end{tabular}


Tabela 4. Skład chemiczny spoiw

Table 4. Chemical composition of binders

\begin{tabular}{|c|c|c|c|c|c|c|c|c|}
\hline \multirow{2}{*}{$\begin{array}{l}\text { Składnik } \\
\text { Component }\end{array}$} & \multicolumn{8}{|c|}{ Zawartość [\% mas.] - Contents [\% wt] } \\
\hline & $\mathrm{SiO}_{2}$ & $\mathrm{Al}_{2} \mathrm{O}_{3}$ & $\mathrm{Fe}_{2} \mathrm{O}_{3}$ & $\mathrm{~K}_{2} \mathrm{O}$ & $\mathrm{CaO}$ & $\mathrm{MgO}$ & $\mathrm{SO}_{3}$ & LOI \\
\hline CEM I 32,5R & 15,00 & 2,78 & 2,72 & 1,21 & 71,06 & 1,38 & 4,56 & 3,64 \\
\hline FA & 55,27 & 26,72 & 6,66 & 3,01 & 2,35 & 0,81 & 0,47 & 4,66 \\
\hline SF & 91,90 & 0,71 & 2,54 & 1,53 & 0,31 & 1,14 & 0,45 & 3,83 \\
\hline
\end{tabular}

Amerykańska norma ASTM C618-12a klasyfikuje popiół lotny na dwie klasy, tzn. F i C, zgodnie z tabelą 5. Stosowany FA można zakwalifikować do klasy F ze względu na uzyskane wyniki z tabeli 4.

Pył krzemionkowy zagęszczony zastosowany w betonie pochodził z Huty Łaziska SA. Jest on odpadem przemysłu hutniczego, który powstaje w piecach łukowo-oporowych przy produkcji że- lazokrzemów czy krzemu metalicznego, na skutek odpowietrzenia i prasowania usunięto część fazy rozproszonej (którą zawiera pył krzemionkowy niezagęszczony). Badania SF potwierdziły, że w składzie chemicznym najwięcej jest krzemionki $\left(\mathrm{SiO}_{2}\right)$ - prawie $92 \%$. Powierzchnię właściwą określono taką samą metodą jak w przypadku FA i wyniosła ona $260 \mathrm{~m}^{2} \cdot \mathrm{kg}^{-1}$.

Tabela 5. Klasyfikacja popiołów według normy ASTM C618-12a

Table 5. Ash classification according to ASTM C 618-12a standard

\begin{tabular}{lccc}
\hline Składnik & \multicolumn{3}{c}{ Zawartość [\% mas.] - Contents [\% wt] } \\
\cline { 2 - 4 } Component & $\begin{array}{c}\text { pucolany } \\
\text { pucolan }\end{array}$ & $\begin{array}{c}\text { popiół lotny klasy F } \\
\text { fly ash class F }\end{array}$ & $\begin{array}{c}\text { popiół lotny klasy C } \\
\text { fly ash class C }\end{array}$ \\
\hline $\mathrm{SiO}_{2}+\mathrm{Al}_{2} \mathrm{O}_{3}+\mathrm{Fe}_{2} \mathrm{O}_{3}$ & $\geq 70$ & $\geq 70$ & $\geq 50$ \\
\hline $\mathrm{SO}_{3}$ & $\leq 4$ & $\leq 5$ & $\leq 5$ \\
\hline $\begin{array}{l}\text { Strata prażenia } \\
\text { Lost of ignition (LOI) }\end{array}$ & $\leq 10$ & $\leq 6$ & $\leq 6$ \\
\hline
\end{tabular}

\section{Metody badań}

Do wykonania badań promieniotwórczości naturalnej wykorzystano miernik typu MAZAR-01. Analizator Mazar 01 przeznaczony jest do określenia stężenia naturalnych pierwiastków promieniotwórczy takich jak rad, potas czy tor. Spełnia ono wymagania wspomnianego rozporządzenia Rady Ministrów z 2007 roku i na podstawie wyników badań tym urządzeniem można udzielić aprobaty technicznej zgodnie ze wspomnianym rozporządzeniem dla materiałów budowlanych oraz odpadów stosowanych chociażby do produkcji materiałów budowlanych, np. betonów stosowanych w budynkach przeznaczonych na pobyt ludzi i inwen- tarza żywego. Część pomiarowa znajduje się w ołowianym domku osłonowym, który zawiera: sondę scyntylacyjną typu SSU-70-2 z kryształem NaJ(T1), przedwzmacniaczem i zasilaczem wysokiego napięcia oraz kalibracyjne źródło izotopowe Cs 137 wykorzystywane do stabilizacji toru pomiarowego. W części odczytowej znajduje się sterownik mikroprocesorowy. Analizator jest przystosowany do współpracy z komputerem PC, dzięki czemu możliwa jest wizualizacja widma spektrometrycznego.

Wskaźniki aktywności oznaczone jako $f_{1}$ i $f_{2}$ określają ilość izotopów. Wskaźnik $f_{1}$ uwzględnia zawartość naturalnych izotopów promieniotwórczych, a je- 
go wartość informuje o narażeniu organizmu na promieniowanie gamma emitowane przez radionuklidy naturalne: ${ }^{40} \mathrm{~K},{ }^{226} \mathrm{Ra}$ oraz ${ }^{228} \mathrm{Th}$. Wskaźnik $f_{2}$ podaje informację o zawartości radu, który jest izotopem macierzystym radonu, dlatego wartość tego wskaźnika określa stopień narażenia na promieniowanie alfa.

$f_{1}=\frac{S_{K}}{3000 \mathrm{~Bq} \cdot \mathrm{kg}^{-1}}+\frac{S_{R a}}{300 \mathrm{~Bq} \cdot \mathrm{kg}^{-1}}+\frac{S_{T h}}{200 \mathrm{~Bq} \cdot \mathrm{kg}^{-1}}$

$f_{2}=S_{\mathrm{Ra}}$

gdzie:

$S_{\mathrm{K}}$-stężenie potasu,

$S_{\mathrm{Ra}}$ - stężenie radu,

$S_{\mathrm{Th}}$ - stężenie toru.

Wskaźniki $f_{1}$ i $f_{2}$ wynoszą odpowiednio 1 i 200 $\mathrm{Bq} \cdot \mathrm{kg}^{-1}$ i nie mogą przekraczać o więcej niż o $20 \%$ tych wartości w odniesieniu do surowców i materiałów budowlanych stosowanych w budynkach przeznaczonych na pobyt ludzi do inwentarza żywego.

Przed wykonaniem badań, urządzenie zostało skalibrowane, a następnie sprawdzone $\mathrm{z}$ użyciem wzorców. W tym czasie przygotowano próbki do badania: krzemionkowych popiołów lotnych, pyłów krzemionkowych zagęszczonych oraz czterech rodzajów betonu. Próbki betonowe miały kształt walców. Walce rozdrobniono na kruszarce szczękowej, po czym przesiano przez sito o boku oczka $2 \mathrm{~mm}$.
Metodą kwartowania odseparowano średnio trzykilogramowe próbki. Następnie próbki suszono do stałej masy w suszarce $\mathrm{z}$ wentylatorem $\mathrm{w}$ temperaturze $105^{\circ} \mathrm{C}$. Po wystudzeniu, próbki zostały umieszczone w pojemniku typu Marinell o objętości $1700 \mathrm{~cm}^{3}$. Pojemniki wcześniej oczyszczono i zważono $\mathrm{z}$ dokładnością do $1 \mathrm{~g}$. Po umieszczeniu próbki w pojemnikach oraz odpowiednim jej ubiciu, pojemnik z próbka zabezpieczano i odstawiano na bok w celu stabilizacji próbki na siedem dni. Przed wykonaniem badań obliczono tło dla próbek na aluminiowym wzorcu masy. Po analizie tła, próbkę umieszczano w domku pomiarowym i wykonano kolejno pomiary przygotowanych próbek.

\section{WYNIKI}

Uzyskane wyniki badań dodatków do betonu oraz betonów przedstawiono $\mathrm{w}$ tabeli 6 . W przypadku zastosowanych FA poziom radioaktywności ponadpięciokrotnie przewyższa wartości wskaźnika $f_{1}$ uzyskane dla SF i kilkukrotnie dla betonu z różną kompozycją dodatków (rys. 2). Dodatkowo FA przewyższa dopuszczalną granicę wskaźnika $f_{1}$ o $0,09 \mathrm{~Bq} \cdot \mathrm{kg}^{-1}$, co zgodnie ze wspomnianym rozporządzeniem Rady Ministrów z 2007 roku dyskwalifikuje zastosowany materiał do wykorzystania go jako surowiec w budynkach przeznaczonych dla ludzi i inwentarza żywego (dopuszczalny poziom $f_{1}$ jest przekroczony o $29 \%$ ). Badania wykazały ponadto wysoki poziom stężenia potasu we wszystkich materiałach w stosunku do stężenia radu

Tabela 6. Wyniki badań promieniotwórczości naturalnej

Table 6. The results of natural radioactivity

\begin{tabular}{lccccc}
\hline \multirow{2}{*}{$\begin{array}{l}\text { Rodzaj materiału } \\
\text { Material type }\end{array}$} & $\begin{array}{c}\text { Stężenie K } \\
\text { Concentration of K }\end{array}$ & $\begin{array}{c}\text { Stężenie Ra } \\
\text { Concentration of Ra }\end{array}$ & $\begin{array}{c}\text { Stężenie Th } \\
\text { Concentration of Th }\end{array}$ & $\begin{array}{c}\text { Wartość wskaźnika aktywności } \\
\text { Values of activity indices }\end{array}$ \\
\cline { 2 - 6 } & & & $f_{1}$ & $f_{2}$ \\
\hline FA & 600,70 & 140,17 & 125,58 & 1,29 & 140,17 \\
\hline SF & 303,41 & 27,20 & 10,07 & 0,24 & 27,20 \\
\hline FA00+SF00 & 296,37 & 9,83 & 6,27 & 0,16 & 9,83 \\
\hline FA00+SF10 & 417,91 & 9,92 & 8,74 & 0,21 & 9,92 \\
\hline FA10+SF10 & 417,76 & 13,14 & 10,25 & 0,23 & 13,14 \\
\hline FA20+SF10 & 449,86 & 15,88 & 13,22 & 0,26 & 15,88 \\
\hline
\end{tabular}




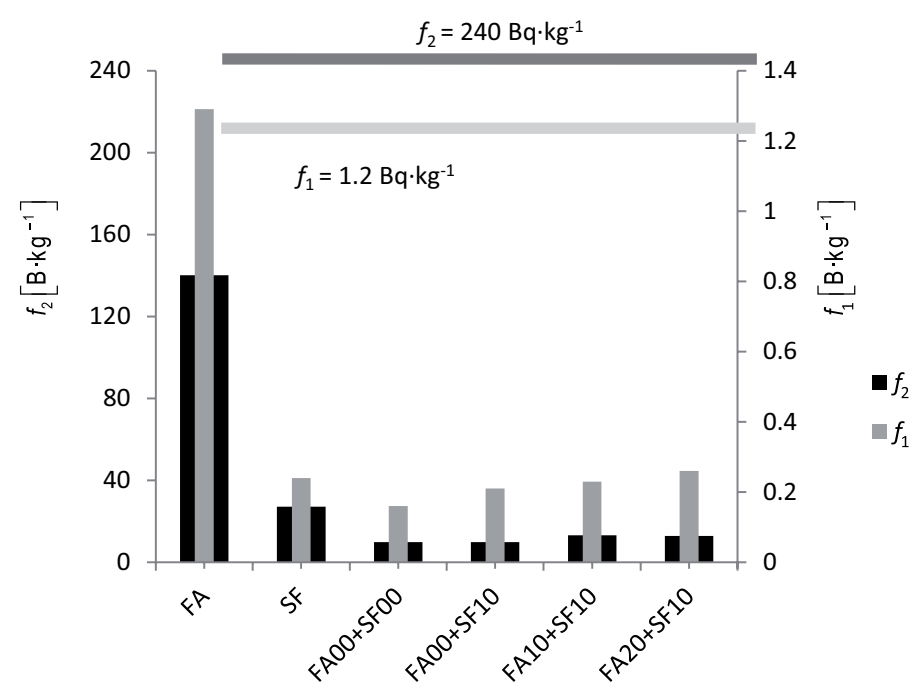

Rys. 2. Wskaźniki radioaktywności $f_{1}$ i $f_{2}$ krzemionkowych popiołów lotnych (FA), mikrokrzemionki zagęszczonej (SF) oraz mieszanek betonowych ze zmienną kompozycją substytutów

Fig. 2. Radioactivity indexes $f_{1}$ and $f_{2}$ of siliceous fly ashes (FA), compacted microsilica fume (SF) and concrete mixtures with variable composition of substitutes

i toru (rys. 3). Decydujący wpływ na przekroczenie wskaźnika $f_{1}$ dla FA miało stężenie radu i toru.

Wykonane badania na betonach ze zmienną ilością dodatków wykazało, że najniższa aktywność $f_{1}$ została wykryta w betonie FA00+SF00 i wyniosła 0,16 $\mathrm{Bq} \cdot \mathrm{kg}^{-1}$, a najwyższa w FA20+SF10 $-0,26 \mathrm{~Bq} \cdot \mathrm{kg}^{-1}$. Zaobserwowano wzrost proporcjonalny do zastosowanej ilości FA. Znaczne różnice można zaobserwować, porównując beton zgodnie ze wskaźnikiem $f_{2}$, gdzie różnice są większe w zależności od zastosowanego FA. Wspomniany parametr zawierał się $\mathrm{w}$ przedziale $13,14-15,88 \mathrm{~Bq} \cdot \mathrm{kg}^{-1}$. Procentowo wskaźnik $f_{2}$ wzrósł w stosunku do betonu referencyjnego: FA10+SF10 o

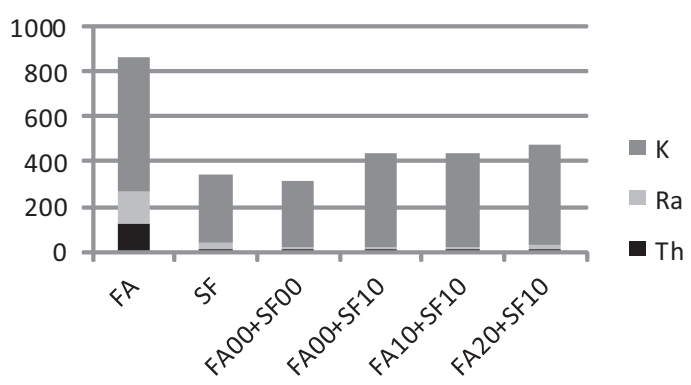

Rys. 3. Poziom stężenia radionuklidów

Fig. 3. The concentration level of radionuclides prawie $33,7 \%$ i o ponad $61,5 \%$ dla FA20+SF 10 . W stosunku do betonu $\mathrm{z}$ dodatkiem jedynie SF odpowiednio o niespełna $1,0 \% f_{1}$ i ponad $31,2 \% f_{2}$.

\section{WNIOSKI}

Zastosowanie mikrokrzemionki zagęszczonej oraz krzemionkowych popiołów lotnych do betonu jest korzystne ze względów ekonomicznych i ekologicznych. Na podstawie informacji uzyskanych z firm pośredniczących w sprzedaży mikrokrzemionki cena $1 \mathrm{t}$ wynosi w granicach 100-150 EUR, więc jest porównywalna bądź nieznacznie wyższa od ceny cementu. Głębszą analizę ekonomiczną przedstawiono w artykule Gila i Golewskiego (2018). Krzemionkowe popioły lotne, powstałe na skutek spalania węgli kamiennych, zawierają w składzie dużą ilość różnych pierwiastków promieniotwórczych. Człowiek w mniejszym stopniu jest narażony na groźne promieniowanie, jakie emitują popioły lotne w pobliżu „pól popiołowych”. Można stwierdzić, że jest bezpieczne zastosowanie tych dodatków do wykonania betonu pod względem wskaźników radioaktywności, mimo przekroczonego wskaźnika $f_{1}$ dodatku, jakim są krzemionkowe popioły lotne. Zagęszczony pył krzemionkowy nie wpłynął w znacznym 
stopniu na radioaktywność betonu. Zastosowanie do betonu krzemionkowych popiołów lotnych również nieznacznie podwyższyło dopuszczalny stopień promieniotwórczości i dzięki temu beton $\mathrm{z}$ dodatkiem krzemionkowych popiołów lotnych i mikrokrzemionki zagęszczonej można zaklasyfikować do bezpiecznych dla zdrowia ludzi materiałów budowlanych.

Zgodnie z dyrektywą 2013/59/Euratom oraz rozporządzeniem Rady Ministrów z 2007 roku w sprawie zawartości ${ }^{40} \mathrm{~K},{ }^{226} \mathrm{Ra} \mathrm{i}{ }^{228} \mathrm{Th}$ w surowcach i materiałach budowlanych (Dz.U. $2007 \mathrm{nr}$ 4, poz. 29), przedstawionych również w pracy Leonardiego i innych (2018), po głębszej analizie stwierdzono, że krzemionkowe popioły lotne bądź inne odpady przemysłowe można stosować do produkcji betonu pod warunkiem, że produkt końcowy (beton) nie przekroczy dopuszczalnych wskaźników aktywności promieniotwórczej.

\section{PIŚMIENNICTWO}

ASTM C618-12a. Standard Specification for Coal Fly Ash and Raw or Calcined Natural Pozzolan for Use in Concrete.

Bem, H., Wieczorkowski, P. i Budzanowski, M. (2002). Evaluation of technologically enhanced natural radiation near the coal-fired power plants in the Lodz region of Poland. Journal of Environmental Radioactivity, 61, 191-201.

Bojakowska, I., Lech, D. i Wołkowicz, S. (2008). Uran i tor w węglach kamiennych i brunatnych ze złóż polskich. Gospodarka Surowcami Mineralnymi, 24 (2), 53-58.

Dyrektywa Rady 2013/59/Euratom z dnia 5 grudnia 2013 r. ustanawiająca podstawowe normy bezpieczeństwa w celu ochrony przed zagrożeniami wynikającymi z narażenia na działanie promieniowania jonizującego oraz uchylająca dyrektywy 89/618/Euratom, 90/641/Euratom, 96/29/Euratom, 97/43/Euratom i 2003/122/Euratom. Dz.U. UE L 13 z 17.01.2014.

Gil, D. i Golewski G. L. (2017b). Wpływ dodatku pyłu krzemionkowego (SF) i krzemionkowych popiołów lotnych (FA) na krytyczny współczynnik intensywności naprężeń betonu. Materiaty Budowlane, 7, 48-49.

Gil, D. i Golewski, G. L. (2017a). Badania odporności na pękanie i wielkości mikrorys w betonie ze zmiennym dodatkiem pyłu krzemionkowego i popiołów lotnych. Materiaty Budowlane, 10, 12-13.
Gil, D. M. i Golewski, G. L. (2016). Analiza odporności na pękanie betonów z dodatkiem popiołów lotnych i mikrokrzemionki. Materiały Budowlane, 11, 116-117.

Gil, D. M. i Golewski, G. L. (2018). Ocena korzyści ekologicznych i ekonomicznych wynikających z wykorzystania $\mathrm{w}$ betonie łącznego dodatku krzemionkowych popiołów lotnych i mikrokrzemionki zagęszczonej. $M a-$ teriaty Budowlane, 10, 22-24.

Główny Urząd Statystyczny [GUS] (2017). Ochrona środowiska 2017. Warszawa.

Golewski, G. L. (2015). Studies of natural radioactivity of concrete with siliceous fly ash addition. Cement - Wapno-Beton, 2, 106-114.

Kovler, K. (2011). Legislative aspects of radiation hazards from both gamma emitters and radon, exhalation of concrete containing coal fly ash. Construction and Building Materials, 25, 3404-3409.

Kovler, K. (2012). Does the utilization of coal fly ash in concrete construction present a radiation hazard? Construction and Building Materials, 29, 158-166.

Kuliczkowski, A., Pluta, R. i Zwierzchowski, D. (1993). Radioaktywność w środowisku człowieka. Monitoring Środowiska Regionu Świętokrzyskiego, 1, 47-50.

Leonardi, F., Bonczyk, M., Nuccetellic, C., Wysocka B. M., Michalik, B., Ampollinic, M., Tonnarini, S., Rubin, J., Niedbalska, K. i Trevisi, R. (2018). A study on natural radioactivity and radon exhalation rate in building materials containing norm residues: preliminary results. Construction and Building Materials, 173, 172-179.

Lubin, J. H., Tomasek, L., Edling, C., Hornung, R. W., Howe, G., Kunz, E., Kusiak, R. A., Morrison, H. I., Radford, E. P., Samet, J. M., Tirmarche, M., Woodward A. i Yao, S. X. (1995). Radon-exposed underground miners and inverse dose-rate (protraction enhancement cement) effects. Health Physics, 69 (4), 494-500.

Mamta, G., Ajah Kumar, M., Rati, V., Sonkawade, R. G., Verma, K. D. i Rajendra, P. (2013). Measurement of natural radioactivity and radon exhalation rate in fly ash samples from a thermal power plant and estimation of radiation doses. Radiation Measurments, 50, 160-165.

Michalik, B. (2006). Naturalna promieniotwórczość w węglu kamiennym i stałych produktach jego spalania. Karbo, $1,2-12$.

Olkuski, T. (2008). Zawartość uranu i toru w węglach polskich i amerykańskich. Polityka Energetyczna, 11 (1), 323-334.

Olkuski, T. i Stala-Szlugaj, K. (2009). Pierwiastki promieniotwórcze w węglu oraz $\mathrm{w}$ produktach odpadowych 
powstających podczas jego spalania. Rocznik Ochrony Środowiska, 11, 913-922.

Pandit, G. G., Sahu, S. K. i Puranik, V. D. (2011). Natural radionuclides from coal fired thermal power plants - estimation of atmospheric release and inhalation risk. Radioprotection, 46, 173-179.

Rozporządzenie Rady Ministrów z dnia 18 stycznia 2005 r. w sprawie dawek granicznych promieniowania jonizującego (Dz.U. $2005 \mathrm{nr}$ 20, poz. 168).

Rozporządzenie Rady Ministrów z dnia 2 listopada 2007 r. w sprawie wymagań dotyczących zawartości naturalnych izotopów promieniotwórczych potasu K-40, radu Ra-226 i toru Th-228 w surowcach i materiałach stosowanych w budynkach przeznaczonych na pobyt ludzi i inwentarza żywego, a także w odpadach przemysłowych stosowanych w budownictwie, oraz kontroli zawartości tych izotopów (Dz.U. 2007 nr 4, poz. 29).

Turhan, Ş., Arıkan, I. H., Yücel, B., Varinlioğlu, A. i Köse, A. (2010). Evaluation of the radiological safety aspects of utilization of Turkish coal combustion fly ash in concrete production. Fuel, 89, 2528-2535.

Xinwei, L., Caifeng, Z., Cancan, C. i Wen, L. (2012). Radioactivity level of soil around Baqiao coal-fired power plant in China. Radiation Physics and Chemistry, 81, $1827-1832$.

Zakrzewski, T. (2005). Promieniotwórczość naturalna w budownictwie. Gliwice: WPŚ.

\title{
NATURAL RADIOACTIVITY OF CONCRETE WITH CONCENTRATED SILICA FUME (SF) AND SILICEOUS FLY ASH (FA) ADDITION
}

\begin{abstract}
Natural radiation has been accompanying humans since its inception. They are present in the air, in water, soil or rocks, as well as in building materials that are used to erect building objects. However, a person may be exposed to a greater or lesser extent to the surrounding radioactivity. The paper presents the results of radioactivity testing of concrete with a different composition of the addition of exemplary siliceous fly ash and compacted microsilica fume. It has been proven that material with increased radioactive activity can be safely used in the production of concrete and additionally it meets the restrictive requirements of the Polish regulation of the Council of Ministers of 2017 or Council directive 2013/59/Euratom in the field of protection against active radiation.
\end{abstract}

Key words: natural radioactivity, radionuclide, concrete, fly ash, concentrated silica fume, radioactive safety 
